\title{
RETROSPECTIVE ANALYSIS OF FUTURE MASTERS' TRAINING FOR PROFESSIONAL COMMUNICATION IN THE SCIENTIFIC COMMUNITY
}

\author{
R.Z. Elsakova, sultanbekovarz@susu.ru \\ South Ural State University, Chelyabinsk, Russian Federation
}

\begin{abstract}
The problem of getting future masters ready for professional communication in the scientific community is considered on the basis of a retrospective analysis. This problem is influenced by the processes of internationalization in education and integration of scientific, educational and production areas. The historical retrospective is made on the basis of the following criteria: 1) the formation of masters' education, 2) the development of scientific communication, 3 ) the development of foreign language education, 4) the formation of language for professional purposes. Representing the historiography of the problem the author reveals three main periods: from 45 th to 60 s of the 20 th century; from 70 th to 90 s of the 20 th century; from the beginning of the 2000s to the present. The period before 1945 is considered a preparatory one. It created social, scientific and practical conditions for training future masters for professional communication in the scientific community.

Keywords: retrospective analysis, historiography, period, initial point, key components of the problem, future masters, scientific community, professional communication.
\end{abstract}

\section{Inroduction}

The study of the social and historical background of the problem of future masters' training for professional communication in the scientific community should be carried out by applying a retrospective analysis to the construction of the historiography of the issue we investigate. This, in turn, will allow us to evaluate the experience of solving the problem accumulated in the past, identify positive and negative trends in the development of the studied parameter, predict and search for possible solutions of the problem based on the identified conditions.

Since historiography is interpreted as a chronologically complete and systematic set of information about its development [24], and its construction reflects the historical process, the use of the process approach to the study of the genesis of the studied pedagogical problem will be completely justified. This means that it is necessary to choose and explain the choice of the "initial point" of its origin and determine the evolutionary periods [9].

It is obvious that future masters' training for professional communication in the scientific community from the point of view of its evolution is a complex abstract phenomenon. And in order to give a systematic analysis of the evolution of the scientific and methodological approximation to the problem statement in its modern form, it is necessary to break it down into key components and consider the dynamics of their historical development.

The key components of the problem of future masters' training for professional communication in the scientific community using the potential of the discipline "a foreign language" are: 1) the development of master's degree programs, 2) the development of scientific communication, 3 ) the development of foreign language education, 4) the spread of the language for professional purposes.

A graphical representation of the evolution process of each component separately is presented in Fig. 1. A parallel display of the development process of all components on one graph clearly demonstrates the intersection of all four lines occurred in the 20th century at one point that we will consider «initial», to be more precise, the end of the Great Patriotic War - 1945, which was a turning point in many areas, including scientific, educational and industrial.

Although each of the components by itself arose long before the date that we had chosen as the initial point for representing the historiography of the problem under study, we would consider three main periods (45th-60s of the 20th century - the first period, 70th-90s of the 20th century - the second period, from the beginning of the 2000s to the present - the third period), and we will consider the previous period preparatory, creating social, scientific and practical 


\section{Непрерывное образование в течение жизни...}

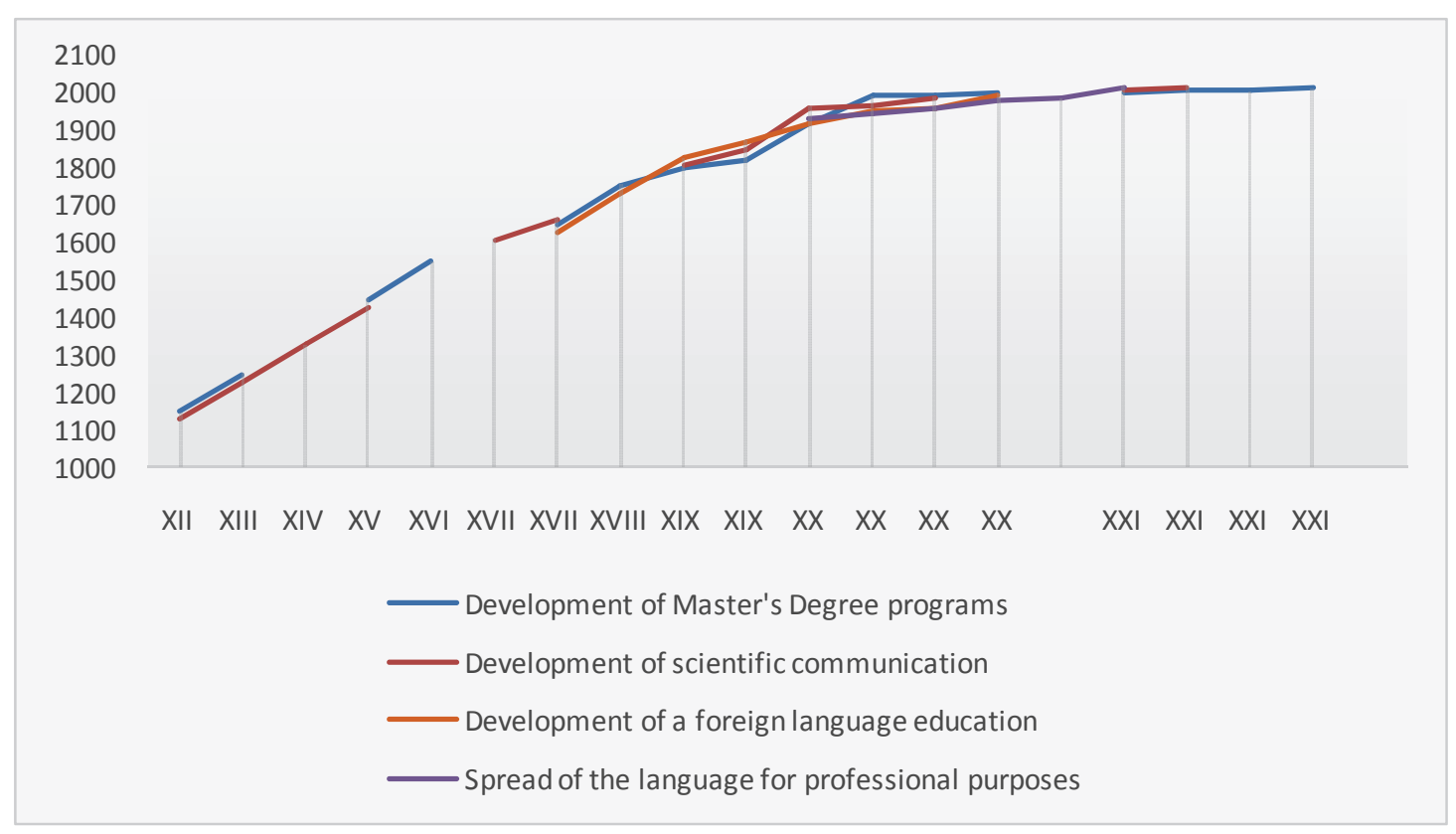

Fig. 1. Historical timeline

conditions for becoming the problem of future masters' training for professional communication in the scientific community. Thus, by the beginning of its evolution, we outlined the following scientific and practical achievements:

- in the direction of masters' training: emerging masters' training as a level of higher education in Russia (introduction of the title of "master", first assignment of a master's degree at the Academy of Sciences) [25], developing master's programs based on European experience, taking into account national characteristics (the appearance of the legislative act "Regulating the production of the scientific degrees" [11]), followed by its abolition (Decree of the Council of People's Commissars of 1918 "On some changes in the composition and structure of state scientists and higher educational institutions of the Russian Republic" [25]);

- in the direction of developing scientific communication: the emergence of an international community of scientists "the republic of scholars", that stimulated the practice of scientific communication by the means of personal meetings and exchanges of letters [12]; the emergence of such forms of presenting scientific results as letters, articles, books; the development of a network of specialized journals and the appearance of the first state scientific academies (the Royal Society of London and the French Academy of Sciences) [18];

- in the direction of a foreign language education: practical study of languages by represen- tatives of some professions (translators, merchants, clergymen); the evolution in the use of foreign languages, starting with the sphere of religion and the translation of the Holy Scriptures [4], as an instrument of learning European culture, as a means of preparing for practical life and nurturing the moral and ethical foundations of the individual and also as a means of intercultural communication; the birth of the grammar-translation method, the immersion method (sending young noblemen to study abroad) and game techniques (cadet theater) [10];

- in the direction of spreading the language for professional purposes: the predominance of the method of logical analysis to the study of the language functioning; the emergence of the idea of creating an artificial language that can remove the boundaries that exist in the field of specialists' communication [15].

Thus, the preparatory period created a certain basis for the problem statement. At this period the phenomenon under study is not the object of scientific analysis, its occurrence is spontaneous and is carried out in four directions.

\section{Results and discussion}

First period - 45th-60s of the 20th century

The period from 1945 to the $60 \mathrm{~s}$ of the 20th century is considered the first stage. As it is known, during this period the USSR, the USA and their allies were participants in the Cold War and were involved in the nuclear missile arms race, which resulted in the threat of nuclear war. In these conditions, in the post-war period, higher 
education institutions became a "source of manpower" for various industries. The number of scientists, research institutions, including research institutes and their branches, increased. In the wake of the revival of education and science, normative documents were worked out and approved, providing the basis for bachelors' and masters' training in universities under the leadership of the chairman of the Union State Committee for Education G.A. Yagodin, but their implementation was never launched [25].

The intensification of scientific processes influenced the development of scientific communication. Moreover, in the United States, the study of this area receives institutional support by creating the Committee on Scientific and Technical Communication (1966) [18]. At the same time, the second historical form of scientific communication, The Invisible College, started its functioning. The hypothesis of "Invisible colleges" was first put forward by J. Price, who by "Invisible college" meant informal contacts between the elite of the most productive scientists within the research field.

Technologization of production processes, scientific and technical growth formed a demand for a certain "international" language, and English became one. People needed the language for their personal development in the professional sphere [1]. However, due to the fact that the grammar-translation method prevailed in foreign language methods of teaching until the $1950 \mathrm{~s}$, this led to the separation of grammar knowledge from practical language proficiency. Therefore, at conferences and in the periodical publications, the necessity of a theoretical understanding of the practical methodology of teaching languages at schools and universities began to be widely discussed. Expanding controversy led to the fact that in 1961 a resolution of the Council of Ministers of the USSR "On improving the study of foreign languages" was issued, which indicated the increasing importance of knowledge of foreign languages by specialists in various fields of science and technology due to the expansion of international relations of the USSR. As a result, the task to create industry-specific teaching aids, vocational guidance in teaching languages in higher education institutions, as well as the practical methods of foreign languages teaching was brought to the foreground. During this period, such methodologists as B.A. Lapidus, S.K. Folomkina, V.V. Morozenko and some others began their scientific work. Their works laid the foundation for the teaching methodology in higher education as a theoretically grounded discipline associated with other sciences [13].

In response to a social demand a special direction in Russian linguistics - the theory of language for special purposes - was being formed [15]. And already in 1962, the concept of language for professional communication appeared, which was put forward in accordance with the theory that the language differs depending on the content of the transmitted information, and therefore certain characteristics that single out the language of specialists in various fields of professional activity can be distinguished.

Summarizing everything that has been said above, we note that, during the first period, one can fix the scientific and practical interest in all components of the identified problem (masters' training, scientific communication, foreign language education and language for professional purposes). However, the study of the phenomenon we are interested in has spontaneous and fragmented nature and is not yet the subject of a comprehensive study due to such reasons as the tense political and economic situation, the lack of a social demand for training certain specialists, and the lack of a theoretical and methodological basis for integrative research of the problem.

Second period $-70 s-90$ s of the 20th century

The period 70s-90s of the 20th century is characterized by the political and economic crisis that began in the country, which subsequently led to the destruction of the Soviet Union. A sharp decline in the living standards of the country's population gave rise to problems in the education system, which underwent reconstructing during liberal reforms in Russia in the 1990s.

These reforms also affected masters' education. So, in the early $90 \mathrm{~s}$, two documents were published at once, reviving masters' training in Russia: in 1992, a decree of the Ministry of Science, Higher School and Technical Policy of the Russian Federation "On the introduction of a multi-level structure of higher education in the Russian Federation" [17] was issued, according to which, bachelors' and masters' training began along with training specialists; in 1993 "The regulation on masters' training in the system of multilevel higher education of the Russian Federation" was approved by the Decree of the State Committee of the Russian Federation on Higher Education N 42 [16], thanks to which the spread of master's programs at universities began.

However, in researches in the field of foreign 


\section{Непрерывное образование в течение жизни...}

language education, the focus of interest changed from the language being studied to the learner. The communicative method was developed by E.I. Passov, who put mastering verbal communicative skills of students at the forefront [13].

In the 70s, scientific interest in the study of the nature of various types of English increased. So, in 1977, a European symposium was convened in Vienna and it was devoted to the issues of "language for special purposes". In addition, the popularity of EST, the English language for science and technology, was growing [1].

The study of the linguistic aspects of the language for special purposes pushed the researchers of foreign languages teaching, both in secondary and higher schools, to develop approaches aimed at developing skills and strategies, and particularly, it referred to methods of teaching how to read and understand special literature.

A further change in the development of foreign language education was due to the processes of globalization and modernization of education in the 1990s, which brought the introduction of a competence-and-activity approach and a focus on a "secondary language personality". In other words, knowledge of a foreign language as an instrument of professional intercultural communication became an absolute requirement for any university graduate [22].

Scientific and technological progress and the development of all elements of social production contributed to the evolution of types and forms of scientific communication: electronic journals, Internet publications (publishing articles online before the issue), open archives of scientific articles (arXiv.org, PLoS.org) appeared and created new standards of communication independent from printed scientific journals and publishers [18].

An increase in the amount of scientific information and the ultra-high-speed transmission of information around the world via the Internet led to the formation of an interactive network of scientific communication "Electronic Invisible College", based on the principles of network culture [20]. Within the framework of this culture, the activities of scientists and scientific organizations are transferred to the online environment, the exchange of letters by e-mail replaces the personal correspondence of scientists. Scientific discussions are held on the basis of scientists' social networks, and online exchanges are used in the scientific world as a "market for knowledge and technology".
Summing up the general results of the second period, we can note that a systematic study of individual aspects of the language for special purposes began in order to meet the needs of science and technology, which led to the emergence of new scientific approaches. Along with the theoretical development of the problem, scientists were searching for practical tools to implement this concept in pedagogical practice, which also contributed to a more intensive study of the issue. At the same time, by the end of the period, a normative base had appeared, thanks to which the deployment of master's programs as a level of education at universities began. Scientific and technological progress also influenced the change in the types and forms of communication in the scientific community, introducing an online format in the Internet environment.

Third period - the beginning of 2000 s

up to the present

The third period of the historical development of the problem - from the beginning of the 2000 s up to the present. The indicated period is characterized by the sociocultural transformation of the world community: the world is becoming digital, and the Internet is the main platform for all forms of activity and communication. As a result of boundary-spanning between states the problems of mankind become global in nature, ethnic conflicts get intensified on the basis of terrorist attacks, mass disruptions of public order for political reasons.

Globalization processes have had a direct impact on education [7, 19]. So, in 2003, Russia took an important step towards integration into the global educational space by joining the Bologna process at the Berlin meeting of European education ministers, followed by signing a number of important documents that determined the fate of masters' education in Russia [2, 14]. Among them are the introduction of Dublin descriptors and the adoption of a European framework for higher education qualifications [2], establishing framework requirements for learning outcomes in three cycles of higher education, including a master's program; Federal Law of 24.10.2007 No. 232-FL “On Amending Certain Legislative Acts of the Russian Federation (in the Part of Establishing Levels of Higher Professional Education)" [5], which codified by law the introduction of a two-level system of higher education and Federal Law No. 273-FL of 2012 "On education in the Russian Federation" [6], which determined that "bachelor" and "master" 
are qualifications. As a result, the reforms in the field of education led to the fact that in 2012 a multi-level system of higher education was introduced in almost all universities in the Russian Federation.

In the current international situation, due to the integration of Russia into the world educational, scientific and economic space, the goals and objectives of foreign language education are changing, which requires teachers to review educational standards, develop new curricula and plans, methods and technologies in the field of language training of a modern specialist, taking into account professional aspects [21]. At the same time, the intercultural paradigm of teaching foreign languages becomes a priority.

Theoretical study of the language for specific purposes is going in two directions: linguistic (functional approach to learning the language as a system-structural phenomenon) and didactic (teaching methods LSP) [8]. If in the 60s LSP was opposed to language for general purposes, now it is considered as a combination of language means used in oral and written texts.

Scientific communication in the 21 st century is becoming a separate professional and academic discipline. To illustrate this trend, it is worth mentioning the publication of a collected book prepared by the General Directorate of the European Commission for Research and Development, combining more than 100 educational programs on scientific communication and journalism in Europe (2010). Moreover, the ITMO University (St. Petersburg) launched the first educational course on scientific communication "SciComm Mission" (2015). As a professional discipline, scientific communication includes such activities as communication in research organizations, scientific journalism, work in centers of science, scientific policy and more. As an academic discipline, scientific communication is engaged in the study of issues related to the processes of translation and perception of scientific information in society [3].

Summarizing the third period, we can note that science has accumulated extensive experience in solving individual aspects of the problem under study. For the indicated period scientists created a fairly thorough theoretical basis for its solution, thanks to which it becomes possible to study it comprehensively. The main sociohistorical conditions of the problem we are studying are:

- institutionalization of the system of master training as a level of higher education [23], which is focused on research work with a focus on a specific type of professional activity;

- the evolution of scientific communication from the practice of communication between scientists in oral, written and virtual forms to its formation as a professional and academic discipline;

- the formation of the concept of language for professional communication as a tool for interaction between specialists.

\section{Conclusion}

In conclusion we can state that the historiography of the problem under study includes three main periods: 45 th -60 s of the 20th century the first, 70th-90s of the 20th century - the second, from the beginning of the 2000s to the present the third. The period before 1945 is considered preparatory which creates social, scientific and practical conditions for becoming the problem currently important. The first period puts the basis for setting the problem and sparks the scientific and practical interest in all components of the identified problem. However, the study of the phenomenon is rather spontaneous and fragmented and is not yet the subject of a comprehensive study due to political, economic, social and methodological reasons. The second period is characterized by such trends as a more intensive study of the language for science and technology, both practical and theoretical aspects, forming the normative and legislative base for master's programs, developing online forms of communication in the scientific community. The third period can be considered as the most productive one because scientists created a fairly thorough theoretical basis for the solution of the problem. It has become really comprehensive and needs further research.

\section{References}

1. Afanas'eva M.V. [ESP - English for Special Purposes: History and Current Situation]. Humanitarian Sciences.Bulletin of the Financial University, 2012, iss. 3 (7), pp. 68-70. (in Russ.)

2. Baydenko V.I. Bolonskiy protsess: evropeyskiye $i$ natsional'nye struktury kvalifikatsiy [Bologna Process: European and National Structures of Qualifications]. Moscow, Issledovatel'skiy tsentr problem kachestva podgotovki spetsialistov Publ., 2009. 220 p.

3. Braha, J. Science Communication at Scientific Societies. Seminars in Cell \& Developmental Biology, 2017, vol. 70, pp. 85-89. DOI: $10.1016 /$ j.semcdb.2017.05.010 


\section{Непрерывное образование в течение жизни...}

4. Deykova L.A. Stanovleniye $i$ razvitiye inoyazychnogo lingvisticheskogo obrazovaniya $v$ vuzakh Rossii. Avtoref. kand. diss. [Formation and Development of Foreign Language Linguistic Education in Higher Education Institutions in Russia. Abstract of Cand. Diss.]. Ul'yanovsk, 2011.27 p.

5. Federal'nyy zakon "O vnesenii izmeneniy $v$ otdel'nyye zakonodatel'nyye akty Rossiyskoy Federatsii ( $v$ chasti ustanovleniya urovney vysshego professional'nogo obrazovaniya)" ot 24.10.2007 N 232-FZ (poslednyaya redaktsiya) [The Federal Law "On Amending Certain Legislative Acts of the Russian Federation (Regarding the Establishment of Levels of Higher Professional Education)" dated October 24, 2007 N 232-FZ]. Available at: http://www.consultant.ru/ document/cons_doc_LAW_72027/ (accessed 10.02.2020). DOI: $10.275 \overline{3} / \mathrm{rsd} 1061-0014430301$

6. Federal'nyy zakon "Ob obrazovanii $v$ Rossiyskoy Federatsii" ot 29.12.2012 N 273-FZ (poslednyaya redaktsiya) [Federal Law "On Education in the Russian Federation" dated December 29, 2012 N 273-Ф3]. Available at: http:// www.consultant.ru/document/cons_doc_LAW_1 40174/(accessed 10.02.2020).

7. Grechko, P. [Globalisation: Educational Horizons]. Higher Education in Russia, 2005, iss. 11, pp.102-107. (in Russ.)

8. Khomutova T.N. Yazyk dlya spetsial'nykh tseley (LSP): lingvisticheskiy aspekt [Language for Special Purposes (LSP): Linguistic Aspect]. Available at: http://lib.herzen.spb.ru/ text/ khomutova_11_71_96_106.pdf (accessed 10.02.2020).

9. Kotlyarova I.O., Serikov G.N. [Assertion of the Retrospective and Ways to Solve of the Pedagogical Problem]. Bulletin of the South Ural State University. Ser. Education. Pedagogy, 2012, no. 4 (263), pp. 12-17. (in Russ.)

10. Kovaleva E.A. Stanovleniye i razvitiye inoyazychnogo obrazovaniya $v$ otechestvennoy gimnazii XIX - nachala XX vv. Avtoref. kand. diss. [Formation and Development of Foreign Language Education in the National Gymnasium of the 19th - Early 20th Centuries. Abstract of Cand. Diss.]. Moscow, 2012. 21 p.

11. Lebedeva L.I. [Master's Education in the XIX - Early XX Century as an Institute for Training Scientific and Academic Staff in Russia]. Economics of Education, 2008, no. 4, pp. 220-224. (in Russ.)

12. Lomovitskaya V.M. [From the History of Studying Scientific Communication]. Sociology of Science and Technology, 2017, vol. 8, no. 4, pp. 37-44. (in Russ.)

13. Matveenko I.A., Oleynik A.N. [History and Perspectives of Developing Foreign Language Education in Technical Universities (Stating the Problem)]. Almanac of Modern Science and Education, 2007, no. 3-3, pp.130-132. (in Russ.)

14. Medvedev S. [Bologna Process, Russia and Globalization]. Higher Education in Russia, 2006, no. 3, pp. 31-36. (in Russ.)

15. Moskalenko P.I. $K$ voprosu o ponyatii “yazyk dlya spetsial'nykh tseley" i termine, ego oboznachayushchem [More on the Notion "Language for Special Purposes" and the Term denoting it]. Available at: https://moluch.ru/archive/ 153/43249/ (accessed 05.02.2020).

16. Postanovleniye Goskomvuza RF ot 10.08.1993 N 42 "Ob utverzhdenii Polozheniya o magisterskoy podgotovke (magistrature) v sisteme mnogourovnevogo vysshego obrazovaniya Rossiyskoy Federatsii" (Zaregistrirovano v Minyuste $R F$ 16.08.1993 N 329). [Decree of the State Committee of the Russian Federation of 10.08.1993 N 42 "On Approval of the Regulation on Master's Training (Master's Program) in the System of Multilevel Higher Education of the Russian Federation" (Registered in the Ministry of Justice of the Russian Federation on 16.08.1993 N 329)]. Available at: http://www.consultant.ru/document/ cons_doc_LAW_15818/ (accessed 10.02.2020). DOI: $10.18796 / 0041-5790-2017-8-10-14$

17. Postanovleniye Minnauki $R F$ ot 13.03.1992 N 13 "O vvedenii mnogourovnevoy struktury vysshego obrazovaniya $v$ RossiyskoyFederatsii" (vmestes "Polozheniyem o poryadke realizatsii gosudarstvennymi vysshimi uchebnymi zavedeniyami obrazovatel'no-professional'nykh programm raznogo urovnya") [Decree of the Ministry of Science of the Russian Federation of March 13, 1992 N 13 "On the Introduction of a Multi-level Structure of Higher Education in the Russian Federation" (Together with the "Regulation on the Procedure for the Implementation by State Higher Educational Institutions of Educational and Professional Programs at Different Levels")]. Available at: http://www. consultant.ru/cons/cgi/online.cgi?req=doc\&base $=\mathrm{EXP} \& \mathrm{n}=401487 \# 038206473930515683 \quad$ (accessed 10.02.2020). DOI: $10.22416 / 1382-4376-$ 2016-5-56-65

18. Reshetnikova E.V. Nauchnyye kommunikatsii: evolyutsiya form, printsipov organizatsii [Scientific Communication: Evolution of Forms, Principles of Organization]. Available at: 
https://sibsutis.ru/upload/publications/9b3/uxofv wfphpyfwz\%20nlcieeuzqkvzohdesxzhcvdi.pdf (accessed 05.02.2020).

19. Senashenko V.S. [Education and Globalization Processes]. Higher Education in Russia, 2013, no. 1, pp. 48-53. (in Russ.)

20. Shirokanova A.A. Elektronnaya nauchnaya kommunikatsiya $i$ "nevidimyye kolledzhi" $v$ informatsionnom obshchestve [Electronic Scientific Communication and "Invisible Colleges" in Information Society]. Available at: http://elib.bsu. by/bitstream/123456789/14454/1/57-62pdf.pdf (accessed 10.02.2020).

21. Slesarenko I., Abdrashitova M., Mymrina D. Developing Professional Communicative Competence through the Medium of the English Language. INTED 2016 Proceedings, 2016, pp. 3911-3916. DOI: 10.21125/inted.2016.1956

22. Volchenkova K.N., Evsina E.V., Elsakova R.Z., Serebrennikova E.V., Batina E.V.
Mastering Interpersonal and Virtual Communication Skills of the Education Process Participants in E-learning. Proceedings of the 2019 International Conference "Quality Management, Transport and Information Security, Information Technologies" (IT\&QM\&IS), Sochi, 2019, pp. 648-652. DOI: 10.1109/itqmis.2019.8928453

23. Yakimovich B. [Master's Training as an Institute: Experience and Perspectives]. Higher Education in Russia, 2008, no. 2, pp. 21-25. (in Russ.)

24. Yakovleva N.O. [Historiography of a Scientific Problem as a Result of a Historicaland-Pedagogical Analysis]. Modern Higher School: Innovative Aspect, 2009, no. 4, pp. 60-66.

25. Zhukova N.M., ChistovaYa.S. [History of Formation and Development of Master's Educational System in Russia]. Bulletin of FGOU VPO MGAU, 2013, iss. 4, pp. 17-21. (in Russ.)

\title{
РЕТРОСПЕКТИВНЫЙ АНАЛИЗ ПРОБЛЕМЫ ПОДГОТОВКИ БУДУЩИХ МАГИСТРОВ К ПРОФЕССИОНАЛЬНОМУ ОБЩЕНИЮ В НАУЧНОМ СООБЩЕСТВЕ
}

\author{
P.3. Елсакова \\ Южно-Уральский государственный университет, г. Челябинск, Россия
}

\begin{abstract}
В статье представлен ретроспективный анализ проблемы подготовки будущих магистров к профессиональному общению в научном сообществе. Актуальность данной проблемы обусловлена процессами интернационализации в сфере образования и интеграции науки, образования и производства. Историческая ретроспектива обозначена на основе следующих критериев: 1) становление магистерского образования, 2) развитие научной коммуникации, 3) развитие иноязычного образования, 4) становление языка для профессиональных целей. Представляя историографию проблемы, автор выделяет три основных периода: 45-60-е годы XX века - первый этап, 70-90-е годы XX века - второй этап, с начала 2000-х годов до настоящего времени - третий этап. Период до 1945 года назван подготовительным, создавшим нормативные, социальные, научные и практические условия для актуализации проблемы подготовки студентов магистратуры к профессиональному общению в научном сообществе.

Ключевые слова: ретроспективный анализ, историография, период, начальная точка, ключевые компоненты проблемы, будущие магистры, научное сообщество, профессиональное общение.
\end{abstract}




\section{Непрерывное образование в течение жизни...}

\section{Литература}

1. Афанасьева, М.В. ЕSP - английский для специальных иелей: история и современность / М.В. Афанасьева // Гуманитарные науки. Вестник финансового университета. - 2012. - № 3 (7). C. $68-70$.

2. Болонский прочесс: европейские и начиональные структуры квалификаций / под науч. ред. д-ра пед. наук, проф. В.И. Байденко. - М.: Исследоват. центр проблем качества подготовки специалистов, 2009. - 220 c.

3. Braha, J. Science communication at scientific societies / J. Braha // Seminars in Cell \& Developmental Biology. - 2017. - Vol. 70. - P. 85-89.

4. Дейкова, Л.А. Становление и развитие иноязычного лингвистического образования в вузах России: автореф. дис. ... канд. пед. наук / Л.А. Дейкова. - Ульяновск, 2011. - 27 с.

5. Федеральный закон "О внесении изменений в отдельные законодательные акты Российской Федерации (в части установления уровней высшего профессионального образования)» от 24.10.2007 N 232-Ф3. - http://www.consultant.ru/document/cons_doc_LAW_72027/ (dama oбpameния: 10.02.2020).

6. Федеральный закон «Об образовании в Российской Федерации» от 29.12.2012 N 273-Ф3. http://www.consultant.ru/document/cons_doc_LAW_140174/(дата обращения: 10.02.2020).

7. Гречко, П. Глобализаиия: образовательные горизонты / П. Гречко // Высшее образование в России. - 2005. - № 11. - C. 102-107.

8. Хомутова, Т.Н. Язык для специальных иелей (LSP): лингвистический аспект / Т.Н. Хомутова. - http://lib.herzen.spb.ru/text/khomutova_11_71_96_106.pdf(дата обращения: 10.02.2020).

9. Котлярова, И.О. Констатаиия ретроспективы и состояния решения педагогической проблемы / И.О. Котлярова, Г.Н. Сериков // Вестник ЮУрГУ. Серия "Образование. Педагогические науки». - 2012. - № 4 (263). - C. 12-17.

10. Ковалева, Е.А. Становление и развитие иноязычного образования в отечественной гимназии ХІХ-начала ХХ вв.: автореф. дис. ... канд. пед. наук / Е.А. Ковалева. - М.: МПГУ, 2012. - 21 с.

11. Лебедева, Л.И. Магистратура в ХІХ - начале XХ века как институт подготовки научных и научно-педагогических кадров в России / Л.И. Лебедева // Экономика образования. - 2008. № 4. - C. 220-224.

12. Ломовичкая, В.М. Из истории изучения научных коммуникаџий / В.М. Ломовицкая // Сочииология науки и технологий. - 2017. - Т. 8, № 4. - С. 37-44.

13. Матвеенко, И.А. История и перспективы развития иноязычного образования в технических вузах (к постановке вопроса) / И.А. Матвеенко, А.Н. Олейник // Альманах современной науки и образования. - 2007. - № 3-3. - С. 130-132.

14. Медведев, С. Болонский прочесс, Россия и глобализаџия / С. Медведев // Высшее образование в России. - 2006. - № 3. - С. 31-36.

15. Москаленко, П.И. К вопросу о понятии «язык для специальных целей» и термине, его обозначающем / П.И. Москаленко // Молодой ученый. - 2017. - № 19. - C. 410-414. https://moluch.ru/archive/153/43249/ (дата обращения: 05.02.2020).

16. Постановление Госкомвуза РФ от 10.08.1993 N 42 «Об утверждении Положения о магистерской подготовке (магистратуре) в системе многоуровневого высшего образования Российской Федеращии» (Зарегистрировано в Минюсте РФ 16.08.1993 N 329). - http://www. consultant.ru/document/cons_doc_LAW_15818/(дата обращения: 10.02.2020).

17. Постановление Миннауки РФ от 13.03 .1992 N 13 «О введении многоуровневой структуры высшего образования в Российской Федерации» (вместе с "Положением о порядке реализации государственными высшими учебными заведениями образовательно-профессиональныхх программ разного уровня»). - http://www.consultant.ru/cons/cgi/online.cgi? req $=$ doc\&base $=E X P \& n=$ 401487\#038206473930515683(дата обращения: 10.02.2020).

18. Решетникова, Е.В. Научные коммуникачии: эволюиия форм, принципов организачии / E.B. Решетникова. - https://sibsutis.ru/upload/publications/9b3/uxofvwfphpyfwz\%20nlcieeuzqkvzohd csxzhcvdi.pdf (дата обращения: 05.02.2020).

19. Сенашенко, В.С. Образование и процессы глобализащии / В.С. Сенашенко // Высшее образование в России. - 2013. - № 1. - С. 48-53. 
20. Широканова, А.А. Электронная научная коммуникация и «невидимые колледжи» в информационном обществе / A.A. Широканова. - http://elib.bsu.by/bitstream/123456789/14454/1/57-62pdf.pdf (дата обращения: 10.02.2020).

21. Slesarenko, I. Developing professional communicative competence through the medium of the English language / I. Slesarenko, M. Abdrashitova, D. Mymrina // INTED 2016 Proceedings. 2016. - P. 3911-3916.

22. Mastering interpersonal and virtual communication skills of the education process participants in e-learning / K.N. Volchenkova, E.V. Evsina, R.Z. Elsakova et al. // Proceedings of the 2019 International Conference "Quality Management, Transport and Information Security, Information Technologies" (IT\&QM\&IS), Sochi, Russia, 2019. - P. 648-652.

23. Якимович, Б. Институт магистратуры: опыт и перспективы / Б. Якимович // Высшее образование в России. - 2008. - № 2. - С. 21-25.

24. Яковлева, Н.О. Историография научной проблемы как результат историко-педагогического анализа / Н.О. Яковлева // Современная высшая школа: инновачионный аспект. - 2009. № 4. - C. $60-66$.

25. Жукова, Н.М. История становления и развития магистерского образования в России / Н.М. Жукова, Я.С. Чистова // Вестник ФГОУ ВПО МГАУ. - 2013. - № 4. - С. 17-21.

Елсакова Рената Загитовна, аспирант кафедры безопасности жизнедеятельности, ЮжноУральский государственный университет, г. Челябинск, sultanbekovarz@susu.ru.

Поступила в редакцию 29 января 20202.

\section{ОБРАЗЕЦ ЦИТИРОВАНИЯ}

Elsakova, R.Z. Retrospective Analysis of Future Masters' Training for Professional Communication in the Scientific Community / R.Z. Elsakova // Вестник ЮУрГУ. Серия «Образование. Педагогические науки». - 2020. T. 12, № 2. - C. 73-81. DOI: $10.14529 /$ ped200207

\section{FOR CITATION}

Elsakova R.Z. Retrospective Analysis of Future Masters' Training for Professional Communication in the Scientific Community. Bulletin of the South Ural State University. Ser. Education. Educational Sciences. 2020, vol. 12 , no. $2, \quad$ pp. $73-81 . \quad$ DOI: $10.14529 /$ ped200207 